\title{
RANCANG BANGUN APLIKASI COFFEE SHOP DI WILAYAH KOTA SUMBAWA
}

\author{
Abdul Rahman ${ }^{1)}$, Shinta Esabella ${ }^{2)}$, Titi Andriani ${ }^{3)}$, Muhammad Hidayatullah ${ }^{4)}$, Miftahul Haq ${ }^{5)}$ \\ 1),2),3),4),5) Fakultas Teknik, Universitas Teknologi Sumbawa \\ email corresponding author: shinta.esabella@uts.ac.id
}

\begin{abstract}
Abstraksi
Penelitian ini bertujuan untuk merancang dan membangun aplikasi yang memberikan informasi tentang produk, fasilitas, dan lokasi coffee shop di Wilayah Kota Sumbawa menggunakan aplikasi berbasis Android hybrid. Metode pengembangan perangkat lunak yang digunakan dalam penelitian ini adalah Prototype Methode, dimana penelitian diawali dengan tahap komunikasi, kemudian tahap perencanaan aplikasi, pembangunan prototype dengan , tahap evaluasi dan penyerahan aplikasi pada pengguna melalui Google Play Store. Dengan adanya aplikasi yang dihasilkan dalam penelitian ini, telah menjadi media penyebaran data dan informasi baik kepada masyarakat asli Sumbawa maupun masyarakat pendatang untuk mengetahui informasi dan lokasi tempat hangout atau coffee shop yang berada dalam wilayah Kota Sumbawa.
\end{abstract}

Kata Kunci :

Coffee Shop, Android Hybrid, Prototype Methode, Google Play Store

\section{Pendahuluan}

Di zaman moderen, ilmu pengetahuan berkembang sejalan dengan teknologi informasi, sehingga dapat mempermudah manusia dalam menyelesaikan masalah yang dihadapi sehari-hari. Salah satu contoh perkembangan ilmu pengetahuan adalah teknologi yang ada pada mobilephone yang pada awalnya diciptakan hanya untuk mengirim sms (shortmessageservice)atau pesan singkat serta komunikasi suara antar manusia dan semakin berkembang untuk keperluan browsing, hingga dapat membantu kebutuhan sehari-hari baik untuk keperluan bekerja maupun hiburan. Tetapi sekarang kemampuan mobilephone sudah sangat canggih, dimana dulu hanya dapat dilakukan oleh komputer, sekarang dapat dilakukan oleh mobilephone yang cerdas yang dikenal dengan namasmartphone.

Salah satu sistem operasi pada mobile yang digunakan oleh smartphone adalah android. Android adalah sistem operasi untuk smartphone yang yang dikembangkan dari dari Linux [1]. Kelebihan android dibandingkan dengan sistem operasi yang lain pada smartphone adalah sifatnya yang opensource. Dengan sifat android yang opensource, pengembang dapat membuat dan memodifikasi aplikasi sesuai dengan keinginan mereka seperti aplikasi mencari tempat hangout.

Di Kabupaten Sumbawa tempat hangout atau coffee shop semakin banyak menjamur berbanding lurus dengan jumlah pengunjung yang datang ke Kabupaten Sumbawa. Tempat coffeeshop ini menjadi sebuah bisnis yang menjanjikan di era globalisasi yang sedang berkembang saat ini. Permasalahannya tidak banyak bisnis tempat hangout atau coffee shop ini didukung dengan promosi yang optimal, sehingga banyak masyarakat atau target konsumen kurang mengetahui produk yang ditawarkan, luas area coffee shop serta fasilitas yang ada dan juga lokasi dari tempat tersebut.

Berdasarkan masalah diatas, maka dirancang Aplikasi Coffee Shop di Wilayah Kota Sumbawa Berbasis Hybrid. Dimana aplikasi android yang dibangun dengan model hybridakan menampilkan nama, daftar menu, fasilitas, luas dan lokasi dari coffee shop yang ada di wilayah kota Sumbawa.

Diharapkan dengan aplikasi yang dihasilkan mempermudah masyarakat asli Sumbawa maupun pendatang di Sumbawa untuk mengetahui informasi dan lokasi tempat hangout atau coffee shop melalui playstore.

\section{Metode Penelitian}

Adapun metode yang digunakan dalam proses pengumpulan data dan pengembangan perangkat lunak adalah sebagai berikut:

\subsection{Metode Pengumpulan Data}

Metode pengumpulan data yang digunakan dalam penelitian ini adalah metode wawancara. Metode pengumpulan data ini dilakukan dengan caramewawancarai pemilik coffee shop yang ada di wilayah kota Sumbawa.

\subsection{Metode Pengembangan Perangkat Lunak}

Metode pengembangan perangkat lunak yang digunakan dalam penelitian ini adalah metode prototype. Metode pengembangan perangkat lunak prototype cocok digunakan untuk mengembangkan sebuah perangkat yang akan dikembangkan kembali. Metode ini dimulai dengan pengumpulan kebutuhan pengguna, dalam hal ini pengguna dari perangkat yang dikembangkan adalah peserta didik. Kemudian membuat sebuah rancangan kilat yang selanjutnya 
akan dievaluasi kembali sebelum diproduksi secara benar [2][3]. Adapun tahapan dalam penelitian ini adalah sebagai berikut:

2.2.1. Komunikasi

Pada tahap ini dilakukan pengumpulan kebutuhan perangkat lunak yaitu informasi dan lokasi coffeeshop yang ada di wilayah kota Sumbawa.

2.2.2. Perencanaan

Pada tahap ini dilakukan perencanaan seperti penjadwalan pada perangkatlunak yang akan di implementasikan di Aplikasi CoffeeShop di Wilayah Kota Sumbawa berbasis Hybrid.

\subsubsection{Prototype}

Pada tahap ini dilakukan pembuatan mockup atau desain aplikasi dan penulisan kode-kode program.

2.2.4. Evaluasi

Pada tahap ini prototype Aplikasi CoffeeShop di Wilayah Kota SumbawaBerbasis Hybridakandievaluasi dengan menggunakan pengujian blackbox untuk mendapatkan hasil yang diinginkan.

2.2.5. Penyerahan Aplikasi

Pada tahap ini setelah aplikasi selesai di evaluasi dan sesuai yang diinginkan maka Aplikasi CoffeeShop di Wilayah Kota SumbawaBerbasis Hybridakan diserahkan ke pengguna.

\section{Hasil dan Pembahasan}

\subsection{Use Case Diagram}

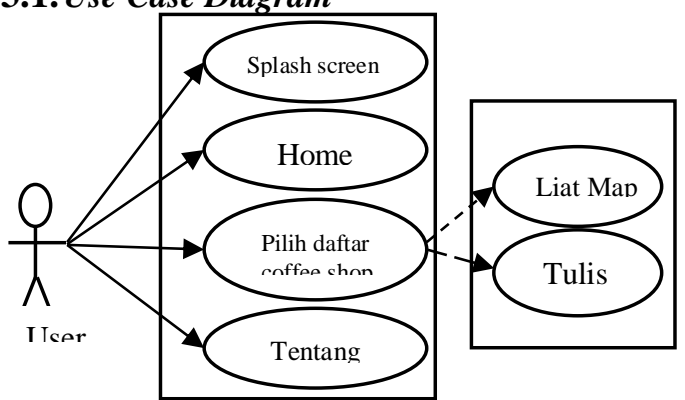

Gambar 1. Use Case Diagram

Pada use case diagram ini menampilkan splash screen pada saat aplikasi pertama kali dijalankan dan selanjutnya menampilkan home atau menu utama dan juga tentang aplikasi. Pada menu utama terdapat pilihan daftar coffeeshop yang kemudian dipilih oleh user. Setelah user memilih salah satu daftar coffeeshop, user dapat menulis review dan melihat map atau lokasi dari coffeeshop tersebut.

\subsection{ClassDiagram}

Class diagram pada Aplikasi CoffeeShop di Wilayah Kota Sumbawa Berbasis Hybrid ini menunjukkan interaksi antar kelas dan aplikasi serta garis yang dihubungkan antar kelas menunjukkan hubungan komunikasi antar class diagram [4]. Gambar dibawah ini merupakan class diagrampada aplikasi adalah sebagai berikut.

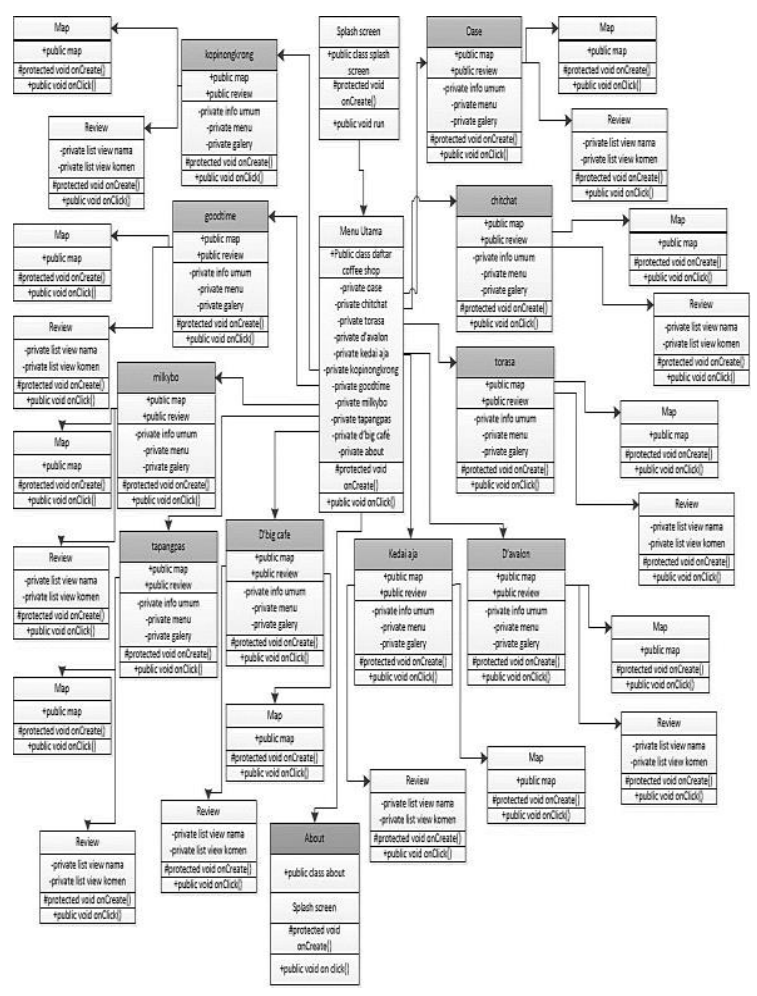

Gambar 2. Class Diagram

\subsection{Rancangan Basis Data}

Perancangan basis data digunakan pada Aplikasi CoffeeShop di Wilayah Kota Sumbawa Berbasis Hybrid adalah dengan mengimplementasikan firebasedatabase sebagai media penyimpanan data. Firebase Database merupakan basis data non-SQL sehingga tidak memerlukan aturan tertentu untuk mengatur struktur basis data [5]. Oleh karena itu, rancangan basis data pada firebase database disimpan dalam format objek JSONtree yang tidak memiliki tabelatau baris seperti data SQL. Pada JSONtree dikenal dengan istilah node untuk setiap proses memasukkan data ke firebase database seperti:

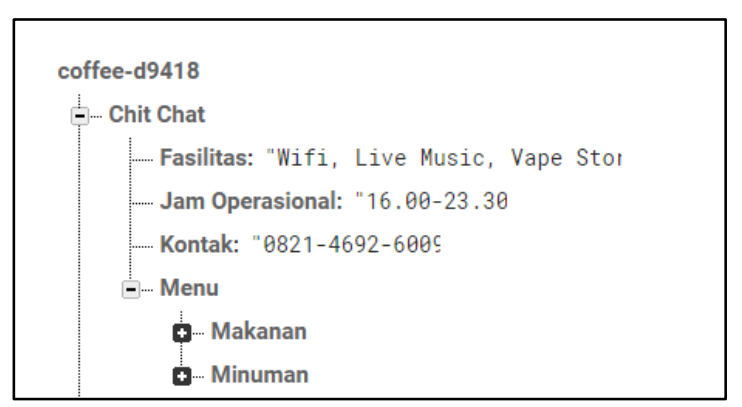

Gambar 3. Format JSON Tree Database

\subsection{Rancangan User Interface}

Adapun perancangan user interface [6] yaitu terdiri dari rancangan splash screen, rancangan home atau menu utama yang berupa daftar coffee shop, rancangan pilih daftar coffee shop, rancangan map, rancangan review, dan rancangan about atau tentang aplikasi. Adapun rancangan user interface sebagai berikut: 


\subsubsection{Rancangan SplashScreen}

Tampilan ini digunakan sebagai tampilan awal yaitu tampilan pembuka. Tampilan ini berisi judul aplikasi untuk memasuki tampilan menu utama aplikasi.

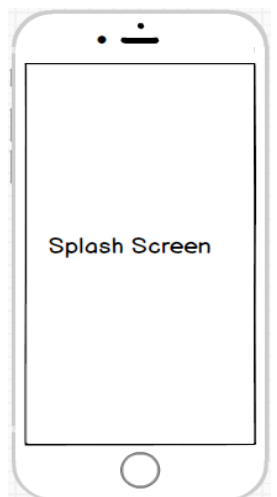

\section{Gambar 4. Rancangan SplashScreen}

Gambar diatas merupakan merupakan mockup dari splash screen ketika user pertama kali membuka Aplikasi Coffee Shop di Wilayah Kota Sumbawa Berbasis Hybrid.

\subsubsection{Rancangan Home Atau Menu Utama}

Adapun rancangan home pada Aplikasi Coffee Shop di Wilayah Kota Sumbawa Berbasis Hybrid seperti di bawah ini.

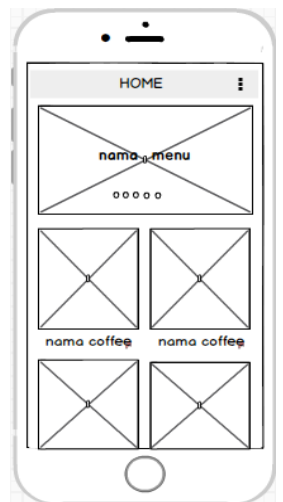

\section{Gambar 5. Rancangan Home}

Pada home atau menu utama merupakan tampilan yang mencul setalah splash screen. Pada home terdapat sepuluh daftar pilihan coffee shop dan ikon dikanan atas. User dapat memilih salah satu daftar coffee shop yang akan menampilkan informasi detail coffee shop sesuai dengan namanya, serta ikon dikanan atas berfungsi menuju halaman informasi tentang aplikasi Coffee Shop di Wilayah Kota Sumbawa Berbasis Hybrid.

\subsubsection{Rancangan Pilih Daftar Coffee Shop}

Tampilan ini menampilkan pilihan daftar dari coffee shop yang di pilih seperti info umum, menu dan galeri, serta ikon map dan review seperti berikut

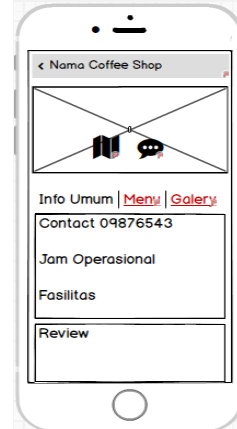

Gambar 6.

Rancangan

Pilih Daftar

Coffee Shop
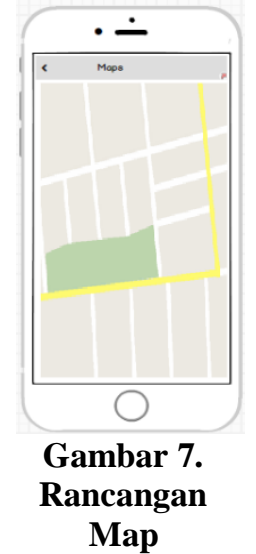

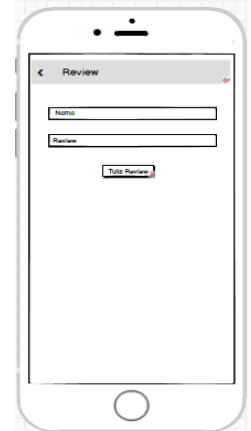

Gambar 8.

Rancangan

Review
Pada gambar 6. Merupakanrancang setelah user memilih daftar coffee shop pada home, terdapat detail dari coffee shop seperti info umum, menu dan galeri, serta ikon map dan review. Selanjutnya userdapat mengklik ikon map yang menampilkan lokasi coffee shop tersebut seperti rancangan map pada gambar 7 . User juga dapat mengklik ikon review untuk menulis review coffee shop seperti rancangan review pada gambar 8.

\subsubsection{Rancangan Tentang Aplikasi}

Rancangan tentangaplikasi berfungsi untuk memberikan informasi tentang Aplikasi Coffee Shop di Wilayah Kota Sumbawa Berbasis Hybrid. Dapat dilihat pada gambar 9 .

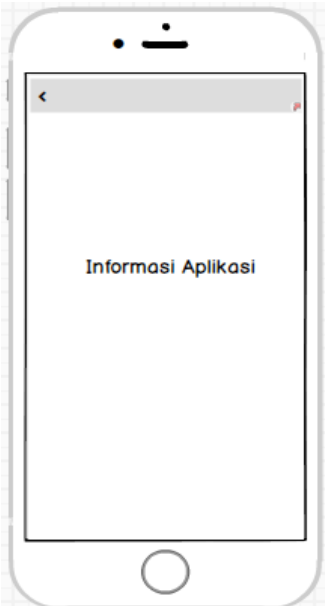

\section{Gambar 9. Rancangan Tentang Aplikasi}

Pada gambar 9. merupakan tampilan rancang tentang aplikasi. Dimana user dapat melihatnya setelah memilih tentang aplikasi pada home atau menu utama aplikasi Coffee Shop di Wilayah Kota Sumbawa Berbasis Hybrid.

\subsection{Implementasi Program}

Implementasi dari hasil perancangan Aplikasi Coffee Shop di Wilayah Kota Sumbawa Berbasis Hybrid yang dikembangan dengan menggunakan FrameworkIonic serta text editor Notepad++ sebagai berikut:

\subsubsection{TampilanSplash Screen}


Adapun tampilan splash screen Aplikasi Coffee Shop di Wilayah Kota Sumbawa Berbasis Hybrid pada smartphone adalah sebagai berikut:

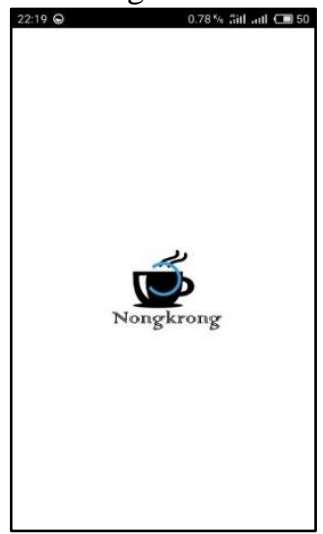

\section{Gambar 10. Tampilan Splash ScreenPada Smartphone}

Pada gambar 4.15. merupakan tampilan awal splash screen ketika membukaAplikasi Coffee Shop di Wilayah Kota Sumbawa sebelum masuk ke menu utama berupa logo dan nama tulisan yaitu nama dari aplikasi.

\subsubsection{Tampilan Home Atau Menu Utama}

Menu utama atau main menu dalam aplikasi mempunyai peranan layaknya terminal atau pintu utama untuk mengakses menu-menu lain dalam suatu aplikasi. Menu utama adalah menu yang berisi link atau akses ke menu yang lain.

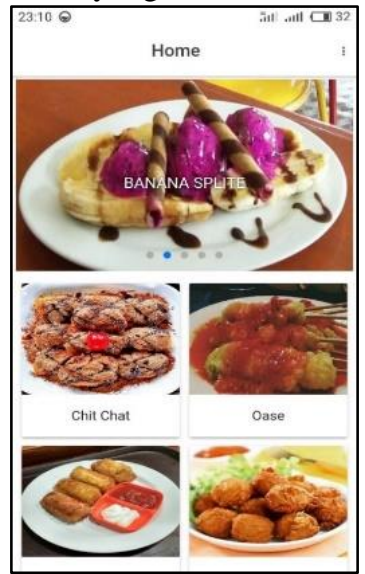

Gambar 11. Rancangan Home Aplikasi

Pada gambar 11. menunjukan menu utama dari aplikasi setelah splash screen. Terdapat daftar coffee shop dan ikon di kanan atas, user dapat memilih salah satu dari coffee shop yang akan diarahkan ke halaman sesuai nama coffeeshop tersebut. Ketika user mengklik ikon dikanan atas, maka aplikasi akan menampilkan informasi mengenai aplikasi dan developer.

3.5.3. Tampilan Pilih Daftar Coffee Shop

Adapun tampilan pilihan dari salah satu daftar coffee shop seperti gambar dibawah ini:

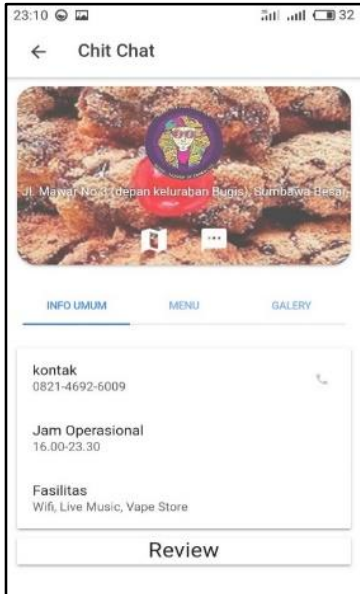

\section{Gambar 12. Tampilan Pilih Daftar CoffeeShop Pada Smartphone}

Pada gambar 12. merupakan salah satu daftar dari coffeeshop yang telah dipilih, dimana user dapat melihat info umum, menu seperti makanan dan minuman serta galery. User juga dapat melihat review dari user lain tentang coffee shop tersebut dan memilih ikon map untuk mengetahui lokasi coffee shop sepert gambar 13. serta ikon review untuk memberikan komentar pada coffee shop tersebut pada gambar 14.

\subsubsection{Tampilan Map}

Adapun tampilan map pada Aplikasi Coffee Shop di Wilayah Kota Sumbawa Berbasis Hybrid sebagai berikut:

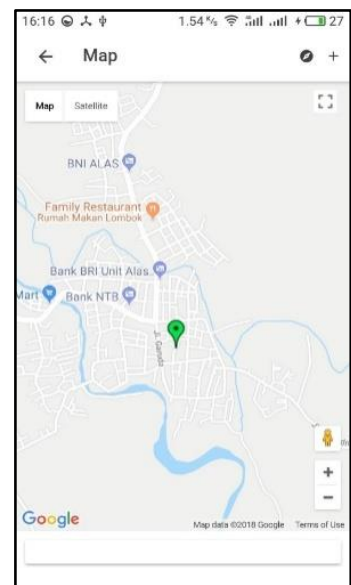

Gambar 13. Tampilan Map

Pada gambar 13. adalah gambar ketika user mengklik ikon map pada halaman sebelumnya. Pada halaman map terdapat dua ikon berwarna merah dan hijau. Dimana ikon berwarna hijau menunjukan lokasi user dan ikon berwarna merah menunjukan lokasi coffee shop tersebut.

\subsubsection{Tampilan Review}

Tampilan review adalah tempat dimana user menulis komentar untuk coffeeshop tersebut. 


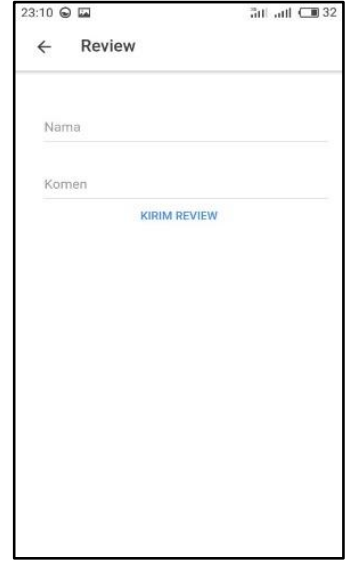

Gambar 14. Tampilan Review

Pada gambar 4.19. adalah gambar ketika user mengklik ikon review pada halaman sebelumnya. Pada halaman review terdapat dua komponen input dan satu tombol. Dimana komponen input pertama user dapat menginputkan namadan yang kedua sebagai komentar dan ketika user mengklik tombol maka secara otomatis akan kembali ke halaman sebelumnya. Dan hasil inputan akan tampil pada halaman tersebut.

\subsubsection{Tampilan Tentang Aplikasi}

Adapaun tampilan Tentang atau about Aplikasi Coffee Shop di Wilayah Kota Sumbawa Berbasis Hybrid sebagai berikut:

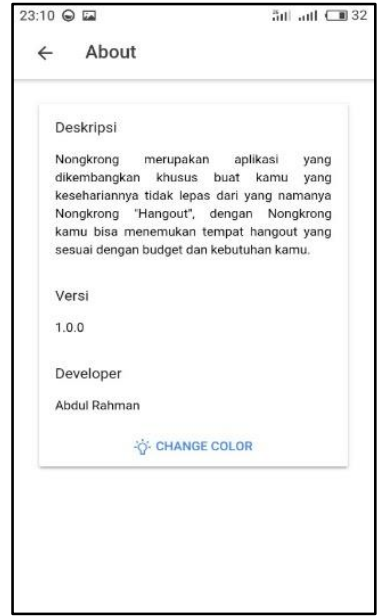

\section{Gambar 15. Tampilan Tentang Aplikasi}

Gambar 15. adalah gambar yang menunjukan informasi seperti deskripsi dari aplikasi, versi dan developer (pengembang) dari Aplikasi Coffee Shop di Wilayah Kota Sumbawa Berbasis Hybrid. User juga dapat mengganti warna aplikasi dengan mengklik tombol change color.

\subsection{Pengujian Perangkat Lunak}

Berikut adalah hasil pengujian perangkat lunak menggunakan pengujian black box [7]:

\section{Uji Fungsionalitas Splash Screen}

Adapun hasil pengujian fungsionalitas splash screen dapat dilihat pada tabel dibawah ini:
Tabel 1. Hasil Pengujian Fungsionalitas Splash Screen

\begin{tabular}{|c|c|c|}
\hline Aksi Aktor & Skenario uji & Hasil Pengujian \\
\hline & & \\
$\begin{array}{c}\text { Memulai } \\
\text { aplikasi }\end{array}$ & $\begin{array}{c}\text { Menampilkan } \\
\text { Splash Screen }\end{array}$ & \\
\hline
\end{tabular}

Hasil pengujian fungsionalitas splash screen menunjukkan bahwa ketika user memulai aplikasi, reaksi perangkat lunak yang ditunjukkan yaitu menampilkan splash screen. Berdasarkan hasil tersebut dapat dikatakan bahwa hasil pengujian fungsionalitas splashscreen adalah sesuai.

2. Uji Fungsionalitas Home Atau Menu Utama Adapun hasil pengujian fungsionalitas home dapat dilihat pada tabel dibawah ini:

Tabel 2. Hasil Pengujian Fungsionalitas Home

\begin{tabular}{|c|l|c|}
\hline $\begin{array}{c}\text { Aksi } \\
\text { Aktor }\end{array}$ & Skenario uji & Hasil Pengujian \\
\hline $\begin{array}{c}\text { Memulai } \\
\text { aplikasi } \\
\text { Menampilkan }\end{array}$ & \begin{tabular}{l} 
Home \\
\hline
\end{tabular} & \\
\hline
\end{tabular}

Hasil pengujian fungsionalitas home menunjukkan bahwa ketika user memulai aplikasi, reaksi sistem yang ditunjukkan setelah splashscreen yaitu menampilkan home atau menu utama yang terdiri dari daftar coffee shopdan ikon about aplikasi di kanan atas. Berdasarkan hasil tersebut dapat dikatakan 
bahwa hasil pengujian fungsionalitas home adalah sesuai.

3. Uji Fungsionalitas Pilih Daftar Coffee Shop Adapun hasil pengujian fungsionalitas pilih salah satu daftar coffee shop dapat dilihat pada tabel dibawah ini:

Tabel 3. Hasil Pengujian Fungsionalitas Pilih Daftar Coffee Shop

\begin{tabular}{|c|c|c|}
\hline $\begin{array}{l}\text { Aksi } \\
\text { Aktor }\end{array}$ & Skenario uji & Hasil Pengujian \\
\hline $\begin{array}{l}\text { Mengklik } \\
\text { salah satu } \\
\text { daftar } \\
\text { coffee } \\
\text { shop }\end{array}$ & $\begin{array}{l}\text { Menampilkan } \\
\text { detail coffee } \\
\text { shop }\end{array}$ & 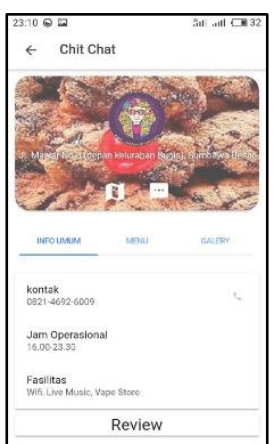 \\
\hline
\end{tabular}

Hasil pengujian fungsionalitas pilih daftar coffeeshop menunjukkan bahwa ketika user mengklik salah satu daftar coffee shop, reaksi perangkat lunak yang ditunjukkan yaitu menampilkan detail coffee shop. Berdasarkan hasil tersebut dapat dikatakan bahwa hasil pengujian fungsionalitas pilih daftar coffee shop adalah sesuai.

4. Uji Fungsionalitas Coffee Shop

Adapun hasil pengujian fungsionalitas map coffee shop dapat dilihat pada tabel dibawah ini:

Tabel 4. Hasil Pengujian Fungsionalitas Map

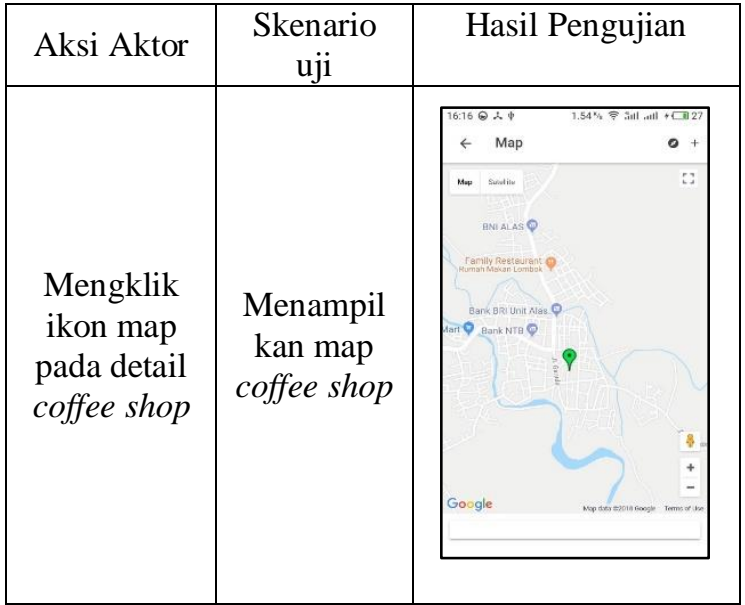

Hasil pengujian fungsionalitas map coffeeshop menunjukkan bahwa ketika user mengklik ikon map pada detail coffee shop, reaksi perangkat lunak yang ditunjukkan yaitu menampilkan map coffee shop. Berdasarkan hasil tersebut dapat dikatakan bahwa hasil pengujian fungsionalitas map coffee shop adalah sesuai.

5. Uji Fungsionalitas Review Coffee Shop Adapun hasil pengujian fungsionalitas reviewcoffee shop dapat dilihat pada tabel dibawah ini:

Tabel 5. Hasil Pengujian Fungsionalitas ReviewCoffee Shop

\begin{tabular}{|c|c|c|}
\hline $\begin{array}{l}\text { Aksi } \\
\text { Aktor }\end{array}$ & Skenario uji & HasilPengujian \\
\hline $\begin{array}{l}\text { Mengklik } \\
\text { ikon } \\
\text { review } \\
\text { pada detail } \\
\text { coffee } \\
\text { shop }\end{array}$ & $\begin{array}{l}\text { Menampilkan } \\
\text { review coffee } \\
\text { shop }\end{array}$ & 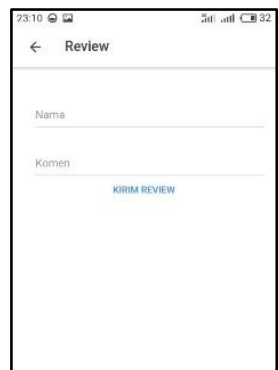 \\
\hline
\end{tabular}

Hasil pengujian fungsionalitas reviewcoffeeshop menunjukkan bahwa ketika user mengklik ikon review pada detail coffee shop, reaksi perangkat lunak yang ditunjukkan yaitu menampilkan reviewcoffee shop. Berdasarkan hasil tersebut dapat dikatakan bahwa hasil pengujian fungsionalitas reviewcoffee shop adalah sesuai.

6. Uji Fungsionalitas Tentang Aplikasi

Adapun hasil pengujian fungsionalitas tentang atau aboutcoffee shop dapat dilihat pada tabel dibawah ini:

Tabel 6. Hasil Pengujian Fungsionalitas Tentang Coffee Shop

\begin{tabular}{|c|c|c|}
\hline $\begin{array}{l}\text { Aksi } \\
\text { Aktor }\end{array}$ & Skenario uji & Hasil Pengujian \\
\hline $\begin{array}{l}\text { Mengklik } \\
\text { ikon } \\
\text { about } \\
\text { pada } \\
\text { home }\end{array}$ & $\begin{array}{l}\text { Menampilkan } \\
\text { about coffee } \\
\text { shop }\end{array}$ & 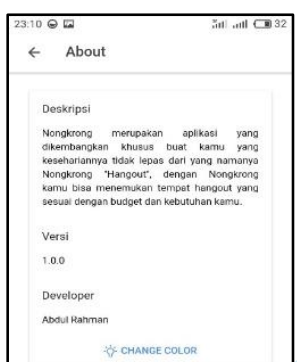 \\
\hline
\end{tabular}


Hasil pengujian fungsionalitas tentang coffeeshop menunjukkan bahwa ketika user mengklik ikon tentangpada home, reaksi perangkat lunak yang ditunjukkan yaitu menampilkan aboutcoffee shop. Berdasarkan hasil tersebut dapat dikatakan bahwa hasil pengujian fungsionalitas tentang coffee shop adalah sesuai.

\subsection{Penyerahan Aplikasi}

Pada tahap ini aplikasi telah selesai di evaluasi dan sesuai yang diinginkan dan siap digunakan seperti gambar dibawah ini:

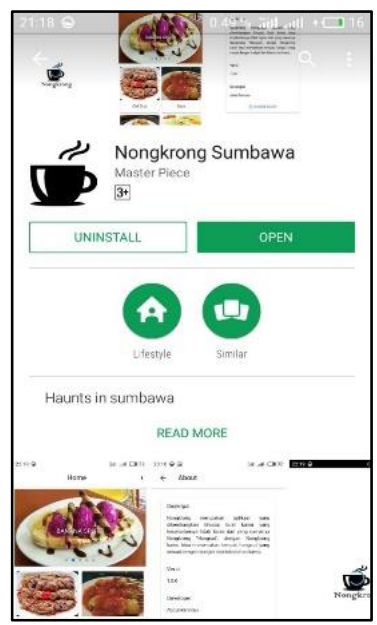

Gambar 16. Tampilan Aplikasi Pada Playstore

Pada gambar 16. merupakan penyerahan aplikasi dengan cara mengupload pada playstore.

\section{Kesimpulan dan Saran \\ Kesimpulan}

Kesimpulan yang dapat diambil dari skripsi ini yaitu Aplikasi CoffeeShop di Wilayah Kota Sumbawa Berbasis Hybrid sudah berhasil dibangun dengan menggunakan Framework Ionic dan databaseFirebasetelah dibuat sesuai dengan perancangan yang telah disusun dan telah di upload ke Googleplaystore. Berdasarkan uji coba dengan smartphone telah berhasil, proses yang ada pada Aplikasi Coffee Shop di Wilayah Kota Sumbawa Berbasis Hybrid telah berjalan dengan baik, seperti info umum, daftar menu, lokasi, dan review coffee shop. Dengan demikian, maka aplikasi ini dapat memberikan informasi untuk masyarakat asli Sumbawa dan masyarakat luar Sumbawa serta media promosi coffee shop tersebut.

\section{Saran}

Berdasarkan kesimpulan yang telah diuraikan diatas, maka saran untuk pengembangan aplikasi ini kedepannya yaitu aplikasi dapat bersifat dinamis dengan penambahan admin maupun dashboard sehingga dapat memudahkan penambahan coffeeshop tanpa perlu kepihak developer dan aplikasi dapat dikembangkan untuk berbagai sistem operasi mobile, agar dapat berjalan di semua sistem operasi mobile.

\section{Daftar Pustaka}

[1] Suranto Aw. (2018). Evaluasi Program Desa Mandiri Informasi Berbasis Aplikasi Android. Jurnal Informasi, Vol. 48, No. 1, e-ISSN : 2502 3837, hlm. 1-13.

[2] Pressman, Roger S. (2012). Rekayasa Perangkat Lunak Pendekatan Praktisi Edisi 7. Yogyakarta: Andi Yogyakarta.

[3] Esabella S, Yudi M, Fitrah A. (2020). Rancang Bangun Aplikasi Mengenal Satera Jontal Sumbawa Berbasis Android. Prosiding Seminar Nasional IPPeMas 2020. ISSN (E) 2721-171, hlm. 192-203

[4] Nugroho, A. (2010). Rekayasa Perangkat Lunak Berbasis Objek dengan Metode USDP. Yogyakarta: Andi Yogyakarta.

[5] Juhara, Zamrony P. (2016). Panduan Lengkap Pemrograman Android. Yogyakarta: Andi Yogyakarta.

[6] Esabella S, Fahri H, Fahmi Y. (2019). Rancang Bangun Aplikasi Media Hidup Sehat Berbasis Android (Studi Kasus Dinas Kesehatan Kabupaten Sumbawa). JINTEKS Vol.1 No.2 , ISSN : 2686-3359, hlm. 143-152

[7] Mustaqbal, Firdaus \& Rahmadi. (2015). "Pengujian Aplikasi Menggunakan Black Box Testing Boundary Value Analysis (Studi Kasus: Aplikasi Prediksi Kelulusan SNMPTN)". Jurnal Ilmiah Teknologi Informasi Terapan, Vol. 1 No 3, ISSN. 2407-3911, hlm.31-40. 